\title{
How the deadwood of different tree species in various stages of decomposition affected nutrient dynamics?
}

\author{
Jarosław Lasota $^{1}$ • Ewa Błońska ${ }^{1}$ - Wojciech Piaszczyk ${ }^{1} \cdot$ Malgorzata Wiecheć $^{1}$
}

Received: 21 August 2017 / Accepted: 19 October 2017 /Published online: 31 October 2017

(C) The Author(s) 2017. This article is an open access publication

\begin{abstract}
Purpose The aim of the study was to estimate how the deadwood of different tree species in various stages of decomposition affected nutrient dynamics.

Materials and methods The deadwood of eight species (common alder, common aspen, common ash, silver fir, pedunculate oak, Norway spruce, common hornbeam and silver birch) was selected. Three logs from each species in the third, fourth and fifth decay classes were chosen for analysis. Wood in the third decay class was characterised by larger hard fragments, fragmented bark and no branches; in the fourth decay class, it was characterised by small pieces and a fragmented bark; and in the fifth decay class, it was characterised by a soft texture and no bark. The investigation was carried out in the Czarna Rózga Reserve in Central Poland. Tension lysimeters were installed under each $\log$ in the humus horizon. The water samples collected from tension lysimeters were chemically analysed in the laboratory. The water chemistry was analysed by means of ion chromatography using a DIONEX ICS 5000 unit. Results and discussion The leachate obtained from different tree species contained different ion concentrations. The high similarity of the concentration of total anions and statistically significant differences in the content of total cations were determined in the leachate from the wood of coniferous and deciduous species. The concentration of the cations increases with the advancement of the
\end{abstract}

Responsible editor: Elżbieta Jamroz

Jarosław Lasota

rllasota@cyf-kr.edu.pl

1 Department of Forest Soil Science, Faculty of Forestry, University of Agriculture, Al. 29 Listopada 46, 31-425 Krakow, Poland decomposition level. A general linear model analysis demonstrates that wood species and the decomposition classes are of equal importance in defining the ion composition of the filtrate leaching from deadwood.

Conclusions Wood at the highest decomposition stage releases more ions to the surface soil layers than wood at the lower decay class. An exception from the rule is the wood of birch, which in the III decay class releases more ions than in its higher decay classes. When comparing the ionic composition of leachate released from wood of coniferous and deciduous tree species, the latter are characterised by higher cation concentrations in comparison with coniferous species. Among the deciduous species, wood of such species as ash, hornbeam, aspen, birch and alder has the most favourable effects on the soil surface horizons through its supply with ionic substances. The ash wood releases high amounts of calcium, hornbeam wood releases magnesium and sodium, and aspen releases calcium, potassium and nitrate anion. From the analysed coniferous species, fir wood has a more favourable effect in terms of ion release to soil than spruce wood.

Keywords Dead lying trees · Decomposition stages · Forest ecosystem $\cdot$ Water chemistry

\section{Introduction}

Deadwood plays a very significant role in a forest ecosystem. It comprises the habitat for diverse autotrophs and heterotrophs, while also acting as an energy source and nutrient reservoir (Zhou et al. 2007; Lassauce et al. 2011; Pichler et al. 2011). The total amount of deadwood is not of key importance for the occurrence of different organisms, rather its quality degree of decomposition and thickness of individual dead trees (Ciach 2011). Currently, following the results of 
a large-area inventory, Polish forests contain a mean of $5.8 \mathrm{~m}^{3} /$ ha of large logs of fallen and standing deadwood. This amounts to 28.1 million $\mathrm{m}^{3}$ standing deadwood and 24.6 million $\mathrm{m}^{3}$ fallen deadwood.

Deadwood is an important carbon pool in forests. During deadwood decomposition, $\mathrm{C}$ can be transferred to the atmosphere (in the form of $\mathrm{CO}_{2}$ ) or it can be added to $\mathrm{C}$ stocks in soils where subsequently it becomes a part of the ongoing $\mathrm{C}$ cycle. Globally, coarse woody debris contains approximately 36-72 Pg of C (Magnússon et al. 2016). One study indicated that there is an accumulation of approximately $1240 \mathrm{Pg}$ of carbon in the biomass and soils of forest ecosystems (VanCamp et al. 2004). Deadwood is the area of storage of macronutrients such as nitrogen $(\mathrm{N})$, phosphorus $(\mathrm{P})$, potassium $(\mathrm{K})$, calcium $(\mathrm{Ca})$ and magnesium $(\mathrm{Mg})$. Similar to $\mathrm{C}$, these nutrients remain in deadwood for a certain period, yet they are eventually released through decomposition. The main processes involved in decomposition of deadwood are heterotrophic respiration, biological transformation, physical fragmentation and leaching (Russell et al. 2015; Magnússon et al. 2016). Leaching of water-dissolved substances accompanies wood decomposition. Tree-specific effects on soil chemistry, throughfall and stemflow composition vary with the element species and are dependent on the supply paths of the elements, their mobility in the environment and their physiological functions in the plant (Bade et al. 2015). Water penetrates deadwood, dissolving and leaching different substances, and as a result, making deadwood poorer in these substances. The significance of these processes at the initial stage of decomposition is low, yet with the advancement of the decomposition processes of deadwood, when microorganisms decompose polymers to more simple, soluble substances, the level of leaching intensifies (Harmon et al. 1986). Numerous components are present at low amounts in fresh wood. Studies have shown that with the advancement of the decay class, the content of these elements in the mass of decomposing wood increases significantly due to the decomposition of carbon compounds. Deadwood is structurally and chemically different from leaf litter and its fate in soil differs from leaf litter (Cotrufo et al. 2013).

The deadwood decomposition is dependent on many factors including tree species, temperature, moisture and substrate quality (Zell et al. 2009; Shorohova and Kapitsa 2014). Wood chemistry, e.g. content of lignin or C:N ratio, and other species-species traits can have a significant influence on the rates of decomposition (Rock et al. 2008). According to Lombardi et al. (2013), the slower decay of lignin compared to cellulose suggested that lignin could be an important long-term source of soil organic carbon and that this process could be greatly affected by forest species mixtures.

The aim of the presented study is to determine the ionic composition of the solution released from deadwood of different tree species, at different decomposition levels. Our specific research questions were the following:

1. How do leaching of nutrients differ between the eight tree species (common alder, common aspen, common ash, silver fir, pedunculate oak, Norway spruce, common hornbeam and silver birch), especially between coniferous and deciduous species?

2. To what degree can we explain the differences in the amount of components released with the level of wood decomposition?

\section{Materials and methods}

\subsection{Sampling sites}

The investigation was carried out in the Czarna Rózga Reserve in Central Poland (Fig. 1). The tree stands within the reserve are of natural origin; the dominant species is alder, further accompanied by the following: fir, ash, birch, beech, pine, oak, hornbeam, aspen and spruce. The study area is characterised by the following conditions of climate: the average annual rainfall is $649 \mathrm{~mm}$, the average annual temperatures amount to $7.4^{\circ} \mathrm{C}$ and the length of the vegetation season lasts 200-210 days. Sample plots were located in the area with a predominance of fluvioglacial sand and loam with gleysols, cambisols and podzols (WRB 2014).

\subsection{Experimental design}

Logs of eight tree species at three different decomposition levels have been selected for the study. The deadwood common alder (Alnus glutinosa), common aspen (Populus tremula), common ash (Fraxinus excelsior), silver fir (Abies $a l b a$ ), pedunculate oak (Quercus robur), Norway spruce (Picea abies), common hornbeam (Carpinus betulus) and silver birch (Betula pendula) were included in the research. Three logs from each species in the third, fourth and fifth decay classes were selected for analysis. The decay classes (DCs) of logs were evaluated with the classification of dead trees developed by Maser et al. (1979) (Table 1). The leachate from deadwood was collected in tension lysimeters. Under each $\log$, one lysimeter was installed at the stem midpoint (log diameter $>25 \mathrm{~cm})$. The lysimeters were constructed of polyethylene tubes with a width of $300 \mathrm{~mm}$. A plastic funnel was placed between the polyethylene tubes and plastic hose, and the plastic funnel was filled with quartz sand. The filtrate went through the lysimeter bottom and plastic hose and was collected in a plastic bottle located below the log, in the soil at the depth of $0-20 \mathrm{~cm}$. The filtrate which would naturally reach the surface horizons of soil passed through to the plastic bottle 


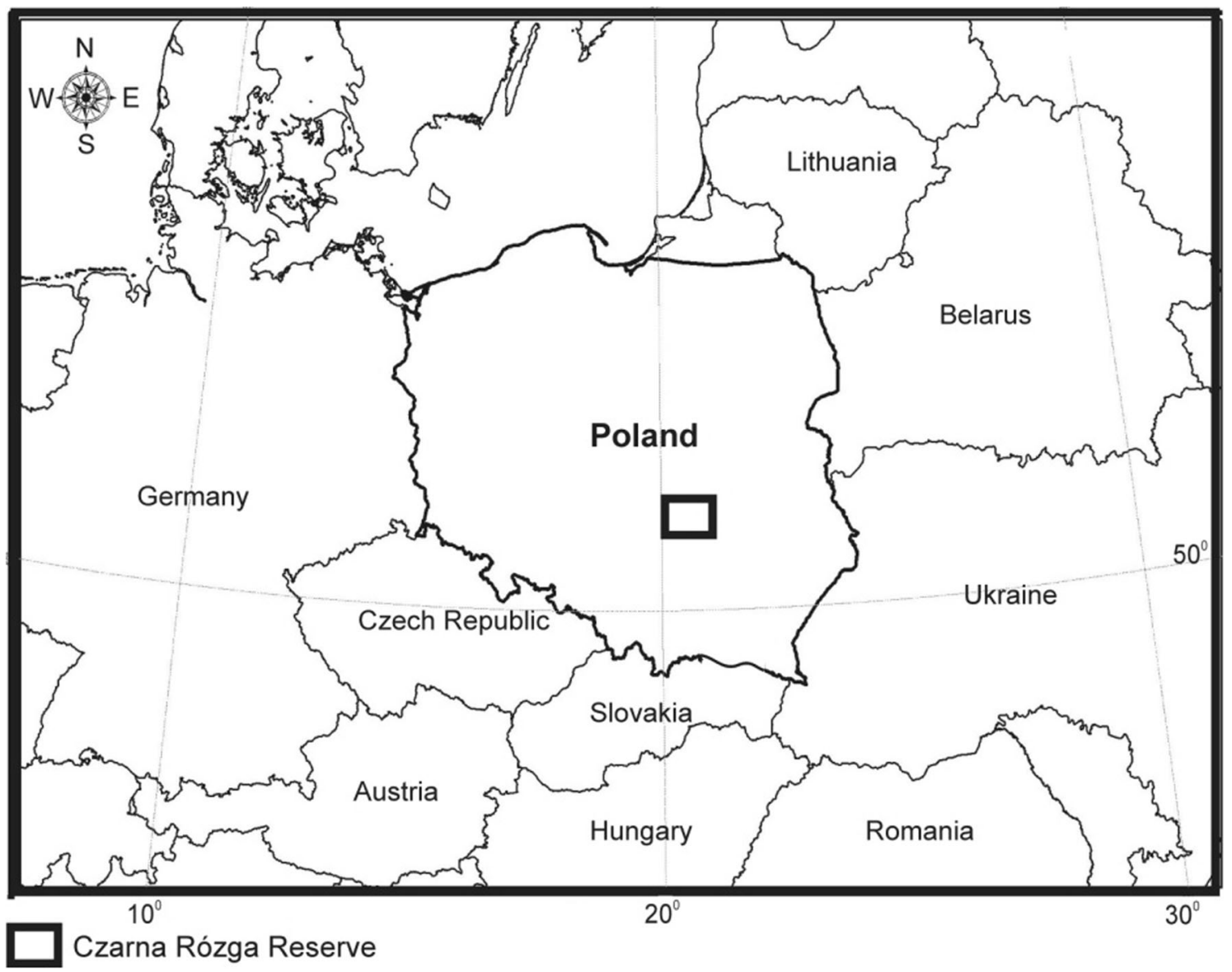

Fig. 1 Sample plot location in Czarna Rózga Reserve in Central Poland

placed at the depth of 0-20 $\mathrm{cm}$ and so had no direct contact with soil. Water samples for analysis were collected at 2-week intervals in the period from the beginning of March to the end of May 2017. For analysis, $100 \mathrm{ml}$ water samples were collected with 48 samples of water being taken in one series. Using the data of the Agrometeorological Bulletins on the precipitation in individual months of the previous years and based on our own observation of the area, a decision was made to obtain deadwood filtrates in the spring. This was due to the precipitation and melting water present in the period from March to May; it would be possible to collect the required volume of filtrates. The collection of filtrates though was completed in May as there was a problem with obtaining the right volume of water for analysis.

\subsection{Laboratory analysis}

Water samples collected from tension lysimeters were chemically analysed in the Forest Environment and Recovery Geochemistry Laboratory at the Forest Faculty, at the University of Agriculture in Kraków. Before the analysis, samples were stored at $4{ }^{\circ} \mathrm{C}$. The water chemistry was
Table 1 Criteria for evaluation of degrees of deadwood decomposition

\begin{tabular}{|c|c|}
\hline Degree & Criteria for evaluation \\
\hline I & $\begin{array}{l}\text { Texture intact, circular, natural color of wood, bark intact, branches }<3 \mathrm{~cm} \text {, } \\
\text { log leaning on branches }\end{array}$ \\
\hline II & $\begin{array}{l}\text { Texture intact, circular, natural color of wood, bark slightly damaged, no branches }<3 \mathrm{~cm} \text {, } \\
\log \text { begins to sink }\end{array}$ \\
\hline III & $\begin{array}{l}\text { Texture-larger hard fragments, circular, faded color of wood, fragmented bark, } \\
\text { no branches }<3 \mathrm{~cm} \text {, almost entire log on the ground }\end{array}$ \\
\hline IV & $\begin{array}{l}\text { Texture - small pieces, oval shape, faded color of wood, no bark, no branches }<3 \mathrm{~cm} \text {, } \\
\text { entire log on the ground }\end{array}$ \\
\hline V & $\begin{array}{l}\text { Texture soft and loose, oval shape, faded color of wood, no bark, no branches }<3 \mathrm{~cm} \text {, } \\
\text { entire on the ground }\end{array}$ \\
\hline
\end{tabular}


analysed by means of ion chromatography using a DIONEX ICS 5000 unit, equipped with a DIONEX AS18 anion column and a DIONEX CS16 cation column. The analytical columns were used to simultaneously determine both the cations and anions in the same water sample. The mean concentration of ions was determined for the analysed period.

\subsection{Statistical analysis}

Based on Ward's method, agglomeration of the tested different species logs was conducted. The similarity between the logs of different species in different degrees of decomposition was investigated. The content of cations and anions determined in the leachate from deadwood was included in the analysis of agglomerations. The differences between the mean values were evaluated using Tukey's test. To reduce the number of variables in the statistical data set and to visualise the multivariate data set as a set of coordinates in a high-dimensional data space, the principal component analysis (PCA) method was used. The PCA method was used to evaluate the relationships between properties of filtrates and decay classes. The decay classes (qualitative variable) were converted into an artificial variable. The coding of variables was performed according to the 0,1 scheme. A general linear model (GLM) was used to investigate the effect of the species and decay classes on the chemical composition of leachate. The statistical significance of the results was verified at the significance level of alpha $=0.05$. All the statistical analyses were performed with Statistica 10 software (2010).

\section{Results}

The leachate obtained in the spring from different tree species contains different ion concentrations. The high similarity of the concentration of total anions and the statistically significant differences in the content of total cations were determined in the leachate from the wood of coniferous and deciduous species. At the III, IV and V decay classes, coniferous wood releases $51.5,48.8$ and $62.2 \mathrm{mg} \mathrm{L}^{-1}$ of total cations, respectively, whereas in III and IV decay classes, deciduous wood releases 55\% more cations and in the $\mathrm{V}$ decay class, the difference is even greater and amounts to 102\% (Figs. 2 and 3). In the leachate from wood of different tree species, high anion concentrations were observed, especially sulfate and phosphate anions; the amounts of which exceeded the concentrations of $730.5 \mathrm{mg} \mathrm{L}^{-1}$ (in the spruce wood in III DC) and $2654.4 \mathrm{mg} \mathrm{L}^{-1}$ (in the case of aspen wood in V DC). Particularly, large amounts of phosphate ions were released from spruce wood in V DC $\left(511.3 \mathrm{mg} \mathrm{L}^{-1}\right)$. In the case of the remaining species, the concentration of this anion was considerably lower and amounted to $1 \mathrm{mg} \mathrm{L}^{-1}$ (alder wood in $\mathrm{V} \mathrm{DC}$ ) to
$154.2 \mathrm{mg} \mathrm{L}^{-1}$ (ash wood in V DC) (Table 2). Wood at a lower decay class typically releases lower amounts of phosphate ions than wood in the V DC. Among the studied species, the wood of ash and fir in the III DC released higher amounts of these ions in comparison to other species in the same decay class $\left(110.5\right.$ and $94.7 \mathrm{mg} \mathrm{L}^{-1}$, respectively).

Analysis of the leachate released from wood at the lower decomposition level (III DC) demonstrates that the highest concentration of the nitrate ion $\left(\mathrm{NO}_{3}{ }^{-}\right)$was found to come from the leachate from alder wood $\left(88.4 \mathrm{mg} \mathrm{L}^{-1}\right)$. The wood of the remaining species at the same stage of decomposition released lower amounts of nitrate ion (from 0.5 to $29.6 \mathrm{mg} \mathrm{L}^{-1}$ ) (Table 2). The leachate originating from wood in the IV DC, in the case of alder wood, was found to contain lower amounts of nitrate ion $\left(57.0 \mathrm{mg} \mathrm{L}^{-1}\right)$; however, in relation to the majority of studied species, such amounts remained statistically significant (the remaining species released from 2.1 to $36.5 \mathrm{mg} \mathrm{L}^{-1}$ ). Wood in the highest decay class in the case of alder wood released only $26.0 \mathrm{mg} \mathrm{L}^{-1}$ of nitrate ion, whereas filtrate from aspen, fir and oak in the V DC contained considerably higher amounts of the ion $\left(179.2,162.1\right.$ and $141.4 \mathrm{mg} \mathrm{L}^{-1}$, respectively) (Table 2 and Fig. 4).

The nitrite ion content is clearly higher in wood at the lower decomposition stage (III and IV DCs) than the concentration of nitrate ions. The leachate from aspen and ash wood was identified as containing the highest amounts of nitrite ion at the mentioned decomposition classes (III and IV DCs). Wood at the highest decomposition stage releases from 6.3 to $226.2 \mathrm{mg} \mathrm{L}^{-1}$ nitrite ions, and the wood of hornbeam and ash contains the highest amounts of the ion (Table 2).

The presence of chloride anions, from 33.7 to $181.3 \mathrm{mg} \mathrm{L}^{-1}$, was observed in the leachate obtained from wood of the analysed species at different decomposition stages. At the III and IV decomposition stages, the tendency for higher concentrations of the ion was determined in the leachate originating from hornbeam, whereas the highest amounts of the ion were released from fir wood in the V DC.

The wood of the examined species releases different amounts of cations $\left(\mathrm{Ca}^{2+}, \mathrm{Mg}^{2+}, \mathrm{K}^{+}, \mathrm{Na}^{+}\right.$and $\left.\mathrm{NH}_{4}^{+}\right)$, the highest concentration being attained by the calcium cation. Typically, with each advancement in decomposition stage, the concentrations of the above cations increase. The wood of birch constitutes an exception in the group of the studied species, as at the earlier decomposition stages, it releases higher amounts of cations than at the V DC. The calcium ion occurred in the leachate originating from wood of different species at amounts ranging from 0.5 to $225.1 \mathrm{mg} \mathrm{L}^{-1}$. The highest concentration of the calcium ion in the case of wood in the lowest decay class (III DC) was identified as originating from birch $\left(68.2 \mathrm{mg} \mathrm{L}^{-1}\right)$; in the wood classified as the IV DC, the concentration of the ion was more similar (21.8- 
Fig. 2 Sum of cations (SC) $\left(\mathrm{mg} \mathrm{L}^{-1}\right)$ in leachate from deadwood of deciduous and coniferous species in various decay classes (DCIII third decay classes, $D C I V$ fourth decay classes and $D C V$ fifth decay classes)

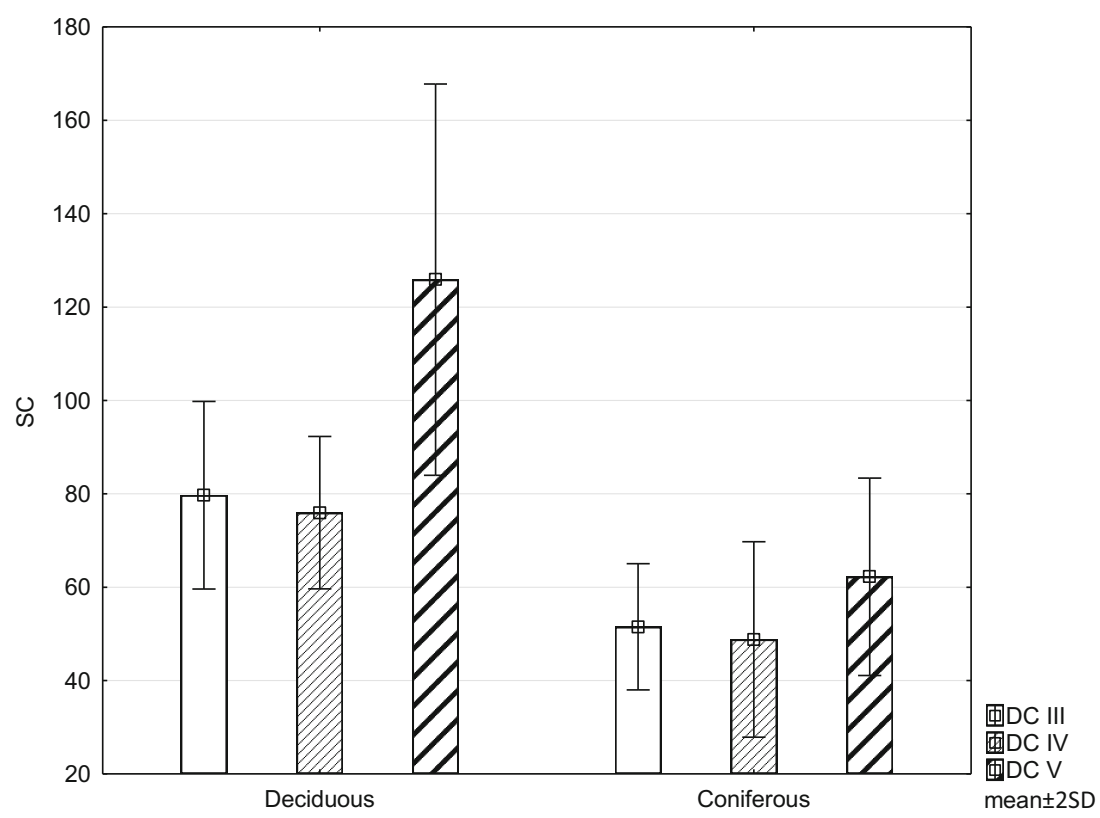

$51.2 \mathrm{mg} \mathrm{L}^{-1}$ ), whereas in the leachate originating from the wood at the highest decomposition stage, the differences in calcium ion concentration were found to be great. The highest concentration of the ion was determined in the leachate from the wood of ash $\left(225.1 \mathrm{mg} \mathrm{L}^{-1}\right)$ whereas the lowest in the leachate was determined as originating from hornbeam $\left(0.5 \mathrm{mg} \mathrm{L}^{-1}\right)$. Whereas in the leachate from other wood species, calcium occurred at levels between 26.0 and $84.4 \mathrm{mg} \mathrm{L}^{-1}$ (Table 3).

Magnesium was found in the analysed wood leachate at lower amounts than those of calcium, i.e. $2.1-16.8 \mathrm{mg} \mathrm{L}^{-1}$ (in leachate from wood in the III DC), 3.4-12.6 $\mathrm{mg} \mathrm{L}^{-1}$ (IV DC) and 3.2-64.4 $\mathrm{mg} \mathrm{L}^{-1}$ (V DC). The highest concentration of the magnesium ion among leachate from wood in the III DC was observed in the filtrate from birch wood $\left(16.8 \mathrm{mg} \mathrm{L}^{-1}\right)$, whereas in the case of the higher decay class wood (IV and V DCs), the highest concentration of the ion was found in the hornbeam wood leachate (Table 3).

Potassium cation was determined in the tested leachates at levels between 4.1 and $46.4 \mathrm{mg} \mathrm{L}^{-1}$, and the minimum and maximum concentration of the ion was determined for the leachate originating from wood in the III DC. The lowest concentration was identified as originating in the leachate from oak wood, and the highest in the leachate from birch wood. In the leachate from wood in the IV decay class, the
Fig. 3 Sum of anions (SA) $\left(\mathrm{mg} \mathrm{L}^{-1}\right)$ in leachate from deadwood of deciduous and coniferous species in various decay classes (DCIII third decay classes, DCIV fourth decay classes and $D C V$ fifth decay classes)

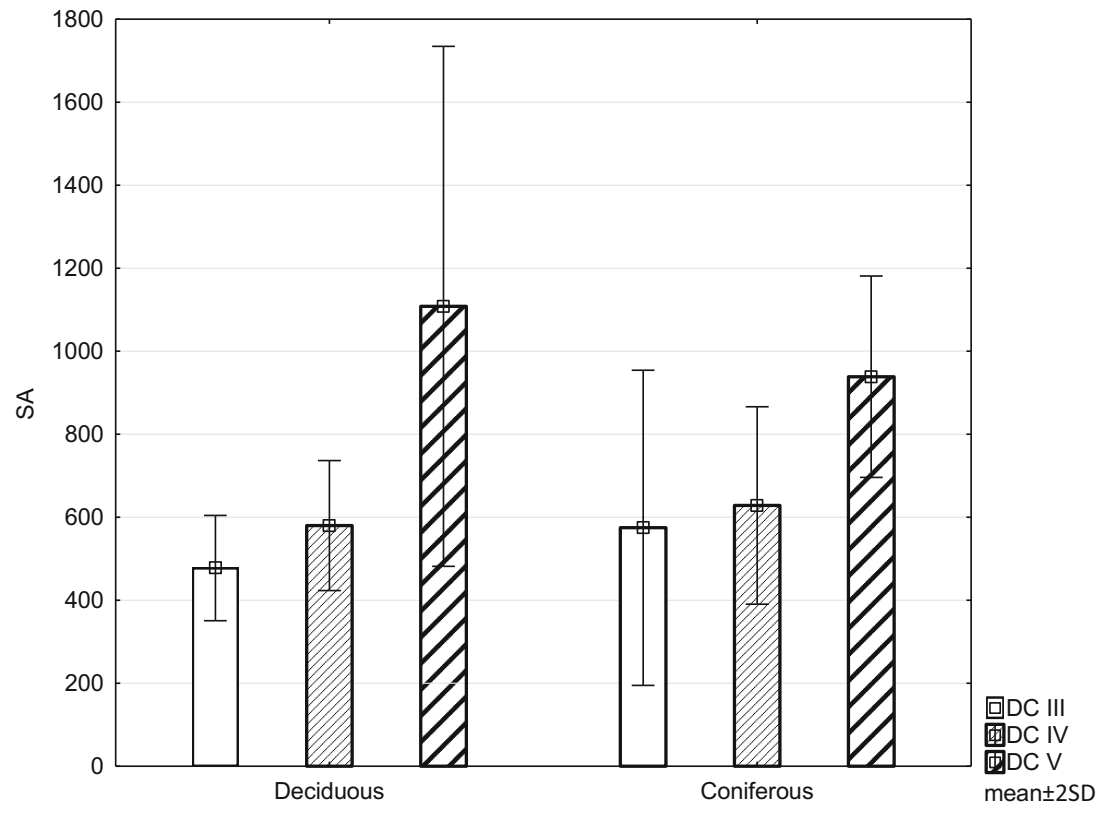


Table 2 Anion concentration $\left(\mathrm{mg} \mathrm{L}^{-1}\right)$ in leachate from deadwood of different species in various decay classes (III, IV and $\mathrm{V}$ )

\begin{tabular}{|c|c|c|c|c|c|c|}
\hline & $\mathrm{DC}$ & $\mathrm{Cl}^{-}$ & $\mathrm{NO}_{2}^{-}$ & $\mathrm{NO}_{3}^{-}$ & $\mathrm{PO}_{4}^{-}$ & $\mathrm{SO}_{4}^{-}$ \\
\hline \multirow[t]{3}{*}{ Ald } & III & $62.3 \pm 6.0^{\mathrm{ab}}$ & $19.6 \pm 7.6^{\mathrm{ab}}$ & $88.4 \pm 36.2^{\mathrm{a}}$ & $68.4 \pm 44.8^{\mathrm{ab}}$ & $323.7 \pm 77.9^{\mathrm{b}}$ \\
\hline & IV & $65.1 \pm 7.4^{\mathrm{ab}}$ & $10.5 \pm 5.7^{\mathrm{bc}}$ & $57.0 \pm 20.1^{\mathrm{a}}$ & $40.8 \pm 17.4^{\mathrm{b}}$ & $352.7 \pm 60.4^{\mathrm{bc}}$ \\
\hline & $\mathrm{V}$ & $88.6 \pm 17.8^{\mathrm{ab}}$ & $6.3 \pm 3.7^{\mathrm{c}}$ & $26.0 \pm 7.0^{\mathrm{b}}$ & $0.2 \pm 0.2^{\mathrm{b}}$ & $491.9 \pm 44.1^{\mathrm{ab}}$ \\
\hline \multirow[t]{3}{*}{ Asp } & III & $34.4 \pm 12.5^{\mathrm{b}}$ & $42.1 \pm 23.4^{\mathrm{a}}$ & $26.5 \pm 18.6^{\mathrm{b}}$ & $24.2 \pm 1.1^{b c}$ & $162.2 \pm 141.9^{\mathrm{bc}}$ \\
\hline & IV & $40.6 \pm 14.3^{\mathrm{b}}$ & $33.1 \pm 6.0^{\mathrm{ab}}$ & $36.5 \pm 21.8^{\mathrm{ab}}$ & $31.0 \pm 5.8^{\mathrm{b}}$ & $570.1 \pm 214.6^{\mathrm{ab}}$ \\
\hline & $\mathrm{V}$ & $125.5 \pm 34.4^{\mathrm{ab}}$ & $19.0 \pm 1.9^{c}$ & $179.2 \pm 72.1^{\mathrm{a}}$ & $45.6 \pm 68.7^{\mathrm{b}}$ & $2654.4 \pm 2241.7^{a}$ \\
\hline \multirow[t]{3}{*}{ Ash } & III & $35.5 \pm 17.5^{\mathrm{b}}$ & $13.6 \pm 6.9^{\mathrm{b}}$ & $0.5 \pm 0.2^{\mathrm{b}}$ & $110.5 \pm 11.6^{\mathrm{a}}$ & $55.5 \pm 29.7^{\mathrm{c}}$ \\
\hline & IV & $33.7 \pm 15.9^{\mathrm{b}}$ & $54.0 \pm 18.3^{\mathrm{a}}$ & $2.1 \pm 1.6^{\mathrm{b}}$ & $121.0 \pm 15.0^{\mathrm{a}}$ & $160.8 \pm 43.8^{\mathrm{c}}$ \\
\hline & $\mathrm{V}$ & $61.9 \pm 20.4^{\mathrm{b}}$ & $123.2 \pm 67.0^{\mathrm{b}}$ & $4.2 \pm 1.2^{\mathrm{b}}$ & $154.2 \pm 23.8^{\mathrm{b}}$ & $233.5 \pm 116.8^{\mathrm{b}}$ \\
\hline \multirow[t]{3}{*}{ Oak } & III & $106.2 \pm 3.6^{\mathrm{ab}}$ & $12.4 \pm 2.1^{\mathrm{b}}$ & $10.8 \pm 1.6^{\mathrm{b}}$ & $0.7 \pm 0.1^{\mathrm{c}}$ & $519.8 \pm 29.7^{\mathrm{a}}$ \\
\hline & IV & $110.8 \pm 4.2^{\mathrm{ab}}$ & $10.8 \pm 3.5^{\mathrm{bc}}$ & $25.8 \pm 5.3^{\mathrm{ab}}$ & $21.4 \pm 8.7^{\mathrm{b}}$ & $309.8 \pm 33.6^{\mathrm{bc}}$ \\
\hline & $\mathrm{V}$ & $84.9 \pm 2.5^{\mathrm{ab}}$ & $8.3 \pm 3.5^{\mathrm{c}}$ & $141.4 \pm 7.1^{\mathrm{a}}$ & $30.2 \pm 14.1^{\mathrm{b}}$ & $227.3 \pm 11.4^{\mathrm{b}}$ \\
\hline \multirow[t]{3}{*}{ Hor } & III & $168.1 \pm 101.4^{\mathrm{a}}$ & $10.4 \pm 5.1^{\mathrm{b}}$ & $0.6 \pm 0.4^{\mathrm{b}}$ & $46.5 \pm 32.0^{\mathrm{bc}}$ & $594.4 \pm 198.1^{\mathrm{a}}$ \\
\hline & IV & $175.4 \pm 89.1^{\mathrm{a}}$ & $34.1 \pm 12.2^{\mathrm{ab}}$ & $8.6 \pm 3.1^{b}$ & $61.6 \pm 16.1^{\mathrm{b}}$ & $809.3 \pm 242.7^{\mathrm{a}}$ \\
\hline & $\mathrm{V}$ & $121.9 \pm 15.7^{\mathrm{ab}}$ & $226.2 \pm 69.7^{\mathrm{a}}$ & $23.6 \pm 13.9^{b}$ & $102.5 \pm 9.7^{\mathrm{b}}$ & $1191.6 \pm 280.7^{\mathrm{ab}}$ \\
\hline \multirow[t]{3}{*}{ Bir } & III & $110.7 \pm 20.2^{\mathrm{ab}}$ & $26.5 \pm 3.5^{\mathrm{ab}}$ & $12.1 \pm 1.9^{\mathrm{b}}$ & $0.8 \pm 0.4^{\mathrm{c}}$ & $179.1 \pm 20.5^{\mathrm{bc}}$ \\
\hline & IV & $107.5 \pm 17.7^{\mathrm{ab}}$ & $20.9 \pm 3.5^{\mathrm{bc}}$ & $17.0 \pm 3.4^{\mathrm{b}}$ & $36.8 \pm 10.4^{\mathrm{b}}$ & $121.9 \pm 18.8^{\mathrm{c}}$ \\
\hline & $\mathrm{V}$ & $70.6 \pm 5.4^{\mathrm{ab}}$ & $14.7 \pm 3.5^{\mathrm{c}}$ & $49.5 \pm 5.9^{\mathrm{b}}$ & $53.9 \pm 34.1^{\mathrm{b}}$ & $89.7 \pm 6.4^{\mathrm{b}}$ \\
\hline \multirow[t]{3}{*}{ Fir } & III & $63.8 \pm 21.0^{\mathrm{ab}}$ & $4.2 \pm 1.5^{\mathrm{b}}$ & $29.6 \pm 14.8^{b}$ & $94.7 \pm 27.3^{\mathrm{a}}$ & $54.0 \pm 2.3^{\mathrm{c}}$ \\
\hline & IV & $60.9 \pm 18.8^{\mathrm{ab}}$ & $5.6 \pm 2.2^{\mathrm{c}}$ & $33.7 \pm 17.3^{\mathrm{ab}}$ & $65.1 \pm 14.8^{\mathrm{b}}$ & $277.3 \pm 54.8^{\mathrm{bc}}$ \\
\hline & $\mathrm{V}$ & $181.3 \pm 106.0^{\mathrm{a}}$ & $10.0 \pm 3.4^{\mathrm{c}}$ & $162.1 \pm 60.0^{\mathrm{a}}$ & $3.7 \pm 5.0^{\mathrm{b}}$ & $498.0 \pm 264.3^{\mathrm{ab}}$ \\
\hline \multirow[t]{3}{*}{ Spr } & III & $125.4 \pm 8.4^{\mathrm{ab}}$ & $24.0 \pm 9.6^{\mathrm{ab}}$ & $6.5 \pm 2.3^{b}$ & $16.8 \pm 5.8^{b c}$ & $730.5 \pm 48.8^{a}$ \\
\hline & IV & $118.2 \pm 10.1^{\mathrm{ab}}$ & $15.6 \pm 6.3^{\mathrm{bc}}$ & $7.1 \pm 2.3^{b}$ & $147.8 \pm 43.1^{\mathrm{a}}$ & $526.2 \pm 51.4^{\mathrm{ab}}$ \\
\hline & $\mathrm{V}$ & $112.2 \pm 10.4^{\mathrm{ab}}$ & $7.5 \pm 4.6^{\mathrm{c}}$ & $9.9 \pm 1.4^{\mathrm{b}}$ & $511.3 \pm 271.6^{\mathrm{a}}$ & $381.4 \pm 47.3^{\mathrm{ab}}$ \\
\hline
\end{tabular}

Different lowercase alphabets in the upper index of the mean values mean significant differences

Ald common alder, Asp common aspen, Ash common ash, Oak pedunculate oak, Hor hornbeam, Bir silver birch, Fir silver fir, Spr Norway spruce content of potassium was more equal, ranging from 6.3 to $38.0 \mathrm{mg} \mathrm{L}^{-1}$, whereas in the leachate obtained from wood at the highest stage of decomposition, the potassium concentration ranged from 8.1 to $36.6 \mathrm{mg} \mathrm{L}^{-1}$, and higher
Fig. $4 \mathrm{NO}_{3}{ }^{-}$concentration $\left(\mathrm{mg} \mathrm{L}^{-1}\right)$ in leachate from deadwood of different species in various decay classes (DC-III, IV and V); Ald common alder, Asp common aspen, Ash common ash, Oak pedunculate oak, Hor hornbeam, Bir silver birch, Fir silver fir, Spr Norway spruce

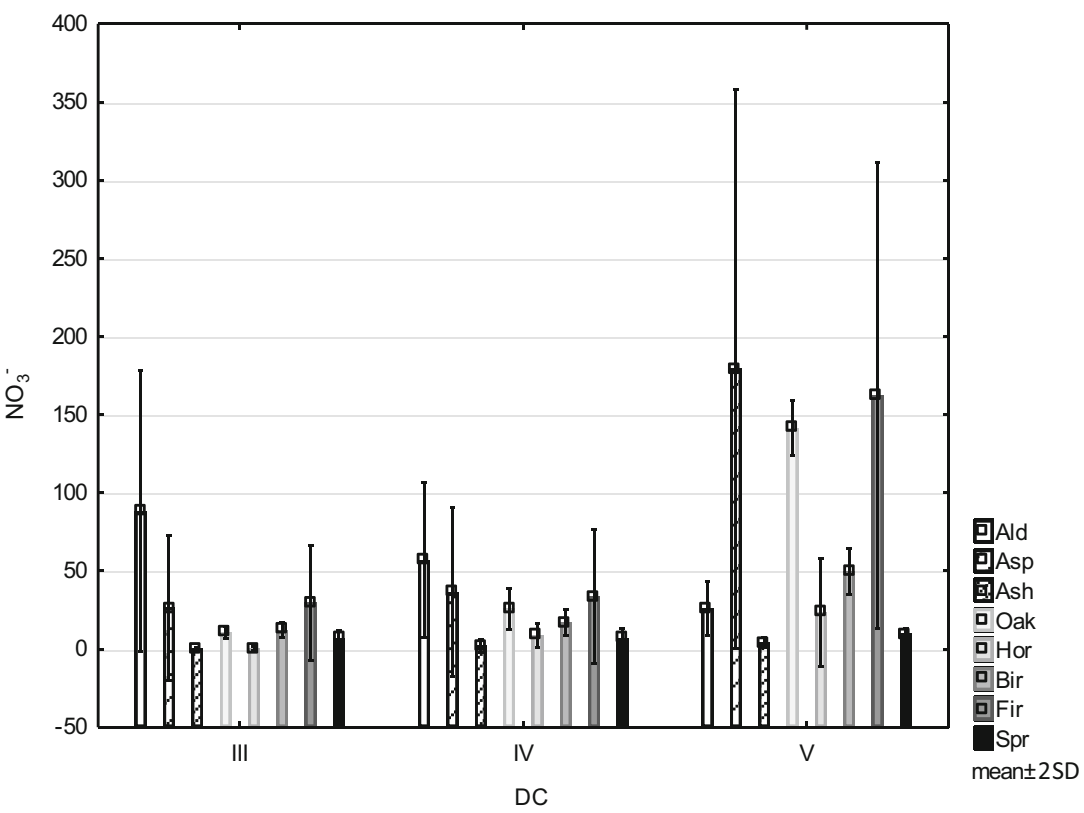


Table 3 Cation concentration $\left(\mathrm{mg} \mathrm{L}^{-1}\right)$ in leachate from deadwood of different species in various decay classes (III, IV and $\mathrm{V}$ )

\begin{tabular}{|c|c|c|c|c|c|c|}
\hline & $\mathrm{DC}$ & $\mathrm{Ca}^{2+}$ & $\mathrm{Mg}^{2+}$ & $\mathrm{K}^{+}$ & $\mathrm{Na}^{+}$ & $\mathrm{NH}_{4}{ }^{+}$ \\
\hline \multirow[t]{3}{*}{ Ald } & III & $10.4 \pm 3.6^{\mathrm{c}}$ & $2.1 \pm 1.1^{\mathrm{b}}$ & $20.8 \pm 10.3^{\mathrm{abc}}$ & $2.3 \pm 1.9^{\mathrm{ab}}$ & $2.6 \pm 1.3^{\mathrm{a}}$ \\
\hline & IV & $21.3 \pm 7.2^{\mathrm{a}}$ & $6.9 \pm 2.3^{\mathrm{ab}}$ & $20.9 \pm 6.1^{\mathrm{ab}}$ & $3.0 \pm 1.5^{\mathrm{ab}}$ & $4.2 \pm 2.7^{\mathrm{a}}$ \\
\hline & $\mathrm{V}$ & $45.3 \pm 28.4^{\mathrm{c}}$ & $25.4 \pm 4.7^{\mathrm{b}}$ & $21.0 \pm 4.6^{\mathrm{ab}}$ & $5.6 \pm 1.4^{\mathrm{ab}}$ & $8.6 \pm 2.8^{\mathrm{a}}$ \\
\hline \multirow[t]{3}{*}{ Asp } & III & $20.3 \pm 8.2^{\mathrm{c}}$ & $2.9 \pm 1.2^{\mathrm{b}}$ & $39.8 \pm 19.8^{\mathrm{a}}$ & $1.3 \pm 0.5^{\mathrm{b}}$ & $1.5 \pm 1.1^{\mathrm{ab}}$ \\
\hline & IV & $35.7 \pm 12.7^{\mathrm{a}}$ & $7.1 \pm 2.5^{\mathrm{ab}}$ & $38.0 \pm 20.2^{\mathrm{a}}$ & $2.0 \pm 1.0^{\mathrm{b}}$ & $2.1 \pm 1.1^{\mathrm{ab}}$ \\
\hline & $\mathrm{V}$ & $84.4 \pm 26.3^{b}$ & $28.2 \pm 16.5^{\mathrm{b}}$ & $36.6 \pm 20.4^{\mathrm{a}}$ & $4.0 \pm 2.6^{\mathrm{ab}}$ & $4.5 \pm 2.4^{\mathrm{bc}}$ \\
\hline \multirow[t]{3}{*}{ Ash } & III & $28.3 \pm 17.3^{\mathrm{bc}}$ & $3.9 \pm 3.2^{\mathrm{b}}$ & $29.3 \pm 13.8^{\mathrm{ab}}$ & $6.7 \pm 1.9^{\mathrm{a}}$ & $0.2 \pm 0.1^{\mathrm{b}}$ \\
\hline & IV & $48.1 \pm 16.9^{\mathrm{a}}$ & $5.7 \pm 2.9^{\mathrm{ab}}$ & $27.4 \pm 12.9^{\mathrm{ab}}$ & $6.1 \pm 1.7^{\mathrm{ab}}$ & $2.0 \pm 1.3^{\mathrm{ab}}$ \\
\hline & $\mathrm{V}$ & $225.1 \pm 25.9^{\mathrm{a}}$ & $23.2 \pm 7.3^{\mathrm{b}}$ & $26.9 \pm 15.1^{\mathrm{ab}}$ & $5.7 \pm 1.7^{\mathrm{ab}}$ & $4.0 \pm 2.6^{\mathrm{bc}}$ \\
\hline \multirow[t]{3}{*}{ Oak } & III & $35.3 \pm 12.6^{\mathrm{abc}}$ & $3.3 \pm 1.4^{\mathrm{b}}$ & $4.1 \pm 2.2^{c}$ & $3.0 \pm 1.6^{\mathrm{ab}}$ & $0.4 \pm 0.3^{\mathrm{b}}$ \\
\hline & IV & $30.1 \pm 14.1^{\mathrm{a}}$ & $3.4 \pm 1.1^{\mathrm{b}}$ & $8.5 \pm 4.0^{\mathrm{ab}}$ & $3.5 \pm 1.8^{\mathrm{ab}}$ & $2.4 \pm 0.9^{\mathrm{ab}}$ \\
\hline & $\mathrm{V}$ & $26.0 \pm 20.0^{\mathrm{cd}}$ & $3.5 \pm 0.6^{\mathrm{c}}$ & $12.0 \pm 7.4^{\mathrm{b}}$ & $4.6 \pm 3.0^{\mathrm{ab}}$ & $6.8 \pm 1.6^{\mathrm{ab}}$ \\
\hline \multirow[t]{3}{*}{ Hor } & III & $51.9 \pm 27.6^{\mathrm{ab}}$ & $5.2 \pm 1.2^{\mathrm{b}}$ & $19.6 \pm 10.6^{\mathrm{abc}}$ & $6.5 \pm 3.4^{\mathrm{a}}$ & $0.6 \pm 0.3^{\mathrm{b}}$ \\
\hline & IV & $32.0 \pm 12.6^{\mathrm{a}}$ & $12.6 \pm 3.6^{\mathrm{a}}$ & $19.1 \pm 10.4^{\mathrm{ab}}$ & $8.7 \pm 4.2^{\mathrm{a}}$ & $1.9 \pm 0.7^{\mathrm{ab}}$ \\
\hline & $\mathrm{V}$ & $0.5 \pm 0.3^{\mathrm{d}}$ & $64.4 \pm 16.9^{\mathrm{a}}$ & $17.1 \pm 9.7^{\mathrm{ab}}$ & $15.9 \pm 7.5^{\mathrm{a}}$ & $4.5 \pm 3.7^{\mathrm{bc}}$ \\
\hline \multirow[t]{3}{*}{ Bir } & III & $68.2 \pm 27.5^{\mathrm{a}}$ & $16.8 \pm 6.1^{\mathrm{a}}$ & $46.4 \pm 14.0^{\mathrm{a}}$ & $4.6 \pm 1.4^{\mathrm{ab}}$ & $3.6 \pm 1.7^{\mathrm{a}}$ \\
\hline & IV & $51.2 \pm 20.9^{\mathrm{a}}$ & $10.8 \pm 4.2^{\mathrm{ab}}$ & $35.2 \pm 9.1^{\mathrm{ab}}$ & $3.1 \pm 1.4^{\mathrm{ab}}$ & $2.8 \pm 1.1^{\mathrm{ab}}$ \\
\hline & $\mathrm{V}$ & $39.7 \pm 19.9^{c}$ & $3.2 \pm 1.2^{\mathrm{c}}$ & $12.7 \pm 2.5^{\mathrm{b}}$ & $2.3 \pm 0.7^{\mathrm{b}}$ & $2.2 \pm 0.6^{\mathrm{c}}$ \\
\hline \multirow[t]{3}{*}{ Fir } & III & $17.7 \pm 6.2^{\mathrm{c}}$ & $2.4 \pm 1.5^{\mathrm{b}}$ & $32.1 \pm 13.5^{\mathrm{ab}}$ & $1.4 \pm 0.9^{\mathrm{b}}$ & $0.2 \pm 0.1^{\mathrm{b}}$ \\
\hline & IV & $25.7 \pm 6.3^{\mathrm{a}}$ & $4.9 \pm 1.7^{\mathrm{b}}$ & $25.1 \pm 11.1^{\mathrm{ab}}$ & $2.9 \pm 1.3^{\mathrm{ab}}$ & $1.1 \pm 0.5^{\mathrm{ab}}$ \\
\hline & $\mathrm{V}$ & $49.6 \pm 7.0^{\mathrm{c}}$ & $6.1 \pm 1.8^{\mathrm{c}}$ & $20.5 \pm 9.1^{\mathrm{ab}}$ & $5.2 \pm 2.0^{\mathrm{ab}}$ & $7.0 \pm 0.6^{\mathrm{ab}}$ \\
\hline \multirow[t]{3}{*}{ Spr } & III & $23.4 \pm 10.3^{\mathrm{bc}}$ & $4.1 \pm 2.0^{\mathrm{b}}$ & $5.9 \pm 1.8^{\mathrm{bc}}$ & $3.7 \pm 2.1^{\mathrm{ab}}$ & $0.1 \pm 0.1^{\mathrm{b}}$ \\
\hline & IV & $23.9 \pm 8.9^{\mathrm{a}}$ & $3.5 \pm 0.9^{\mathrm{b}}$ & $6.3 \pm 2.0^{\mathrm{b}}$ & $3.8 \pm 2.1^{\mathrm{ab}}$ & $0.5 \pm 0.2^{\mathrm{b}}$ \\
\hline & $\mathrm{V}$ & $27.1 \pm 7.1^{\mathrm{cd}}$ & $3.3 \pm 0.6^{\mathrm{c}}$ & $8.1 \pm 1.8^{\mathrm{b}}$ & $4.7 \pm 1.2^{\mathrm{ab}}$ & $6.3 \pm 1.2^{\mathrm{ab}}$ \\
\hline
\end{tabular}

Different lowercase alphabets in the upper index of the mean values mean significant differences

Ald common alder, Asp common aspen, Ash common ash, Oak pedunculate oak, Hor hornbeam, Bir silver birch, Fir silver fir, $\operatorname{Spr}$ Norway spruce concentrations were determined in the leachate from aspen wood (Table 3).

The sodium ion varied to a lower degree among the examined species. It was determined in the examined leachates at the level between 1.3 and $15.9 \mathrm{mg} \mathrm{L}^{-1}$. In the case of leachates originating from wood at the lowest decomposition stage (at the III DC), sodium was determined at the highest amount for the leachate from hornbeam and ash wood. The leachate originating from hornbeam wood in the $\mathrm{V}$ decay class contained the highest amount of sodium (15.9 $\mathrm{mg} \mathrm{L}^{-1}$ ) (Table 3).

The ammonium ion $\left(\mathrm{NH}_{4}{ }^{+}\right)$turned out to be highly variable. In the leachate obtained from wood in the III decay class, the amount of ammonium ions was low $\left(0.1-1.5 \mathrm{mg} \mathrm{L}^{-1}\right)$ with the exception for the leachate originating from birch and alder wood, where the concentration of the ion was 3.6 and $2.6 \mathrm{mg} \mathrm{L}^{-1}$, respectively. In the leachate from wood in the IV DC, the concentration of ammonium ion was more similar among the studied species, with the exception of the alder wood, where its concentration was $4.2 \mathrm{mg} \mathrm{L}^{-1}$. In filtrates from the $\mathrm{V}$ DC wood, the highest amounts of ammonium ion were released by alder $\left(8.6 \mathrm{mg} \mathrm{L}^{-1}\right)$ and spruce, oak and fir wood (6.3-7.0 $\mathrm{mg} \mathrm{L}^{-1}$ ) (Table 3 and Fig. 5).

A GLM analysis demonstrates that wood species and the decomposition level are of equal importance for the ion composition of the filtrate leaching from wood (Table 4). On the other hand, the PCA analysis indicates that the significantly highest concentrations of the most important ions $\left(\mathrm{Mg}^{2+}\right.$, $\mathrm{Ca}^{2+}, \mathrm{NH}_{4}{ }^{+}, \mathrm{NO}_{3}{ }^{-}$) existed in the leachate originating from wood at its highest decomposition level in comparison to leachate from wood in the III and IV decay classes (Fig. 6).

The conducted agglomeration analysis indicates that certain groups of tree species are prominent and are similar in their field of cation composition of the leachate. These groups can be most clearly seen for the leachate originating from wood in the $\mathrm{V}$ decay class (Figs. 7 and 8). In terms of the composition of the released cations, alder and aspen are the most prominent species; the second group comprises spruce, oak, fir and birch, and the last group with similar leachate composition contains hornbeam and ash wood. Considering the composition of anions, an agglomeration analysis indicates similarity of filtrates of such species as 
Fig. $5 \mathrm{NH}_{4}{ }^{+}$concentration $\left(\mathrm{mg} \mathrm{L}^{-1}\right)$ in leachate from deadwood of different species in various decay classes (DC-III, IV and V); Ald common alder, Asp common aspen, Ash common ash, Oak pedunculate oak, Hor hornbeam, Bir silver birch, Fir silver fir, $\operatorname{Spr}$ Norway spruce

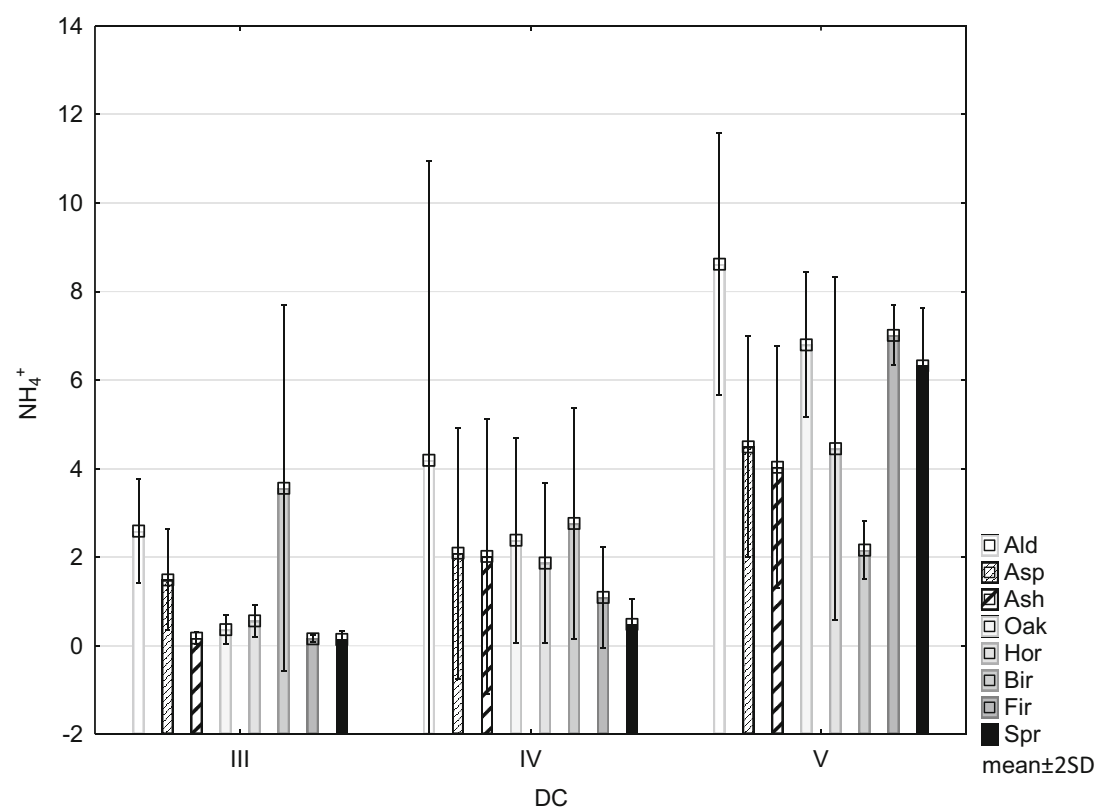

alder, birch and spruce; the second distinctive group is formed by oak, fir and aspen, whereas hornbeam and ash create a separate pair of species.

\section{Discussion}

This study demonstrates that in the majority of examined species, greater amounts of ions are released with the advancement of wood decomposition. The quantity of ions leached from decaying wood typically increases for several reasons. Firstly, with the advancement of decomposition of woodbuilding substances, carbon compounds are decomposed, primarily polysaccharides, and the relative (to wood volume) content of such macronutrients as nitrogen, phosphorus, sulfur, calcium and magnesium changes over time (Laiho and Prescott 2004). As an example, after 14 years of decomposition, the content of phosphorus in the wood of Pinus contorta, Picea glauca and Abies lasiocarpa increased 4.0-, 2.5- and 9.0-fold, respectively, relative to the initial content (Prescott

Table 4 Results of multivariate analysis of variance based on the general linear model (GLM) for the sum of anion and cation, including the species and decay classes

\begin{tabular}{lllllll}
\hline & \multicolumn{2}{l}{ Sum of anion } & & \multicolumn{2}{l}{ Sum of cation } \\
\cline { 2 - 3 } \cline { 7 - 8 } & $F$ & $P$ value & & $F$ & $P$ value \\
\hline Species & 5.63 & $<0.001$ & & 12.11 & $<0.001$ \\
Decay classes & 9.39 & $<0.001$ & & 14.22 & $<0.001$ \\
Decay classes $\times$ species & 3.24 & $<0.001$ & & 6.80 & $<0.001$ \\
\hline
\end{tabular}

Significance effect $(P<0.05)$ are shown in italic and Laiho 2002). Krankina et al. (1999), who analysed changes in the nutrient supply in deadwood of boreal forests, indicated that the nitrogen content during the decomposition process from the I to IV decay classes had increased by $45 \%$ in birch wood, $39 \%$ in spruce wood and $60 \%$ in pine wood. Previous studies indicated that certain elements, e.g. potassium, can be released at a higher rate; thus, their supply in deadwood is significantly reduced with advancing decomposition (Holub et al. 2001; Christensen and Vesterdal 2003; Yang et al. 2010). Kuehne et al. (2008)

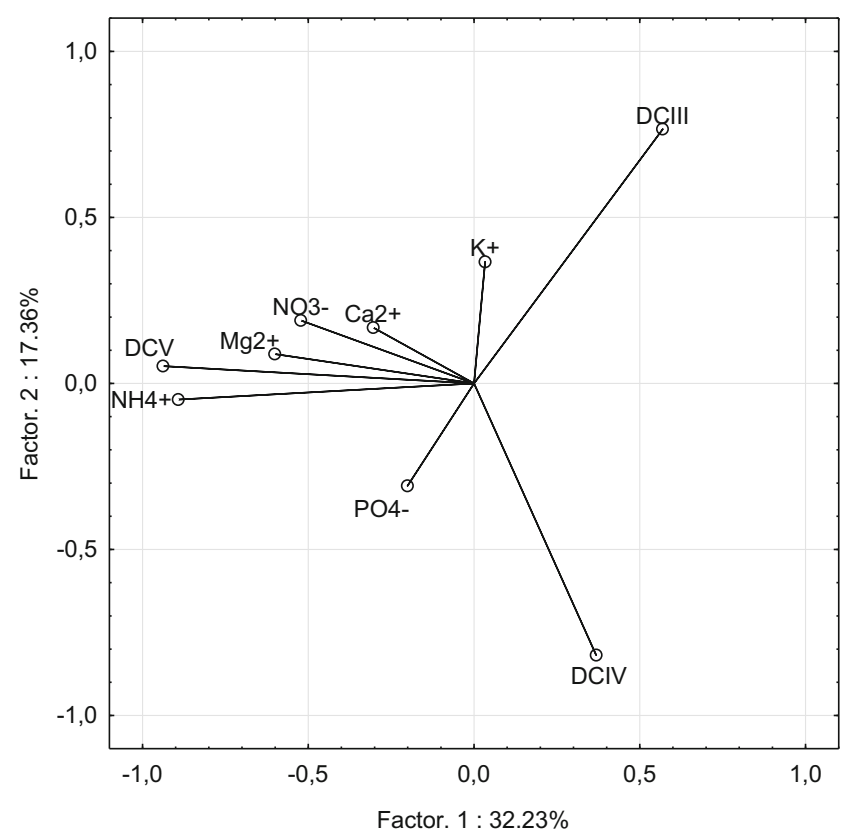

Fig. 6 Diagram of PCA with projection of variables on a plane of the first and second factor of leachate from deadwood in various decay classes (DCIII, DCIV, and DCV) 
Fig. 7 The result of agglomeration with Ward's method of filtrates from deadwood in $\mathrm{V}$ decay classes (variables used in the analysis, cation content); Ald common alder, Asp common aspen, Ash common ash, Oak pedunculate oak, Hor hornbeam, Bir silver birch, Fir silver fir, Spr Norway spruce; 1, 2 and 3-repetitions of logs in each species

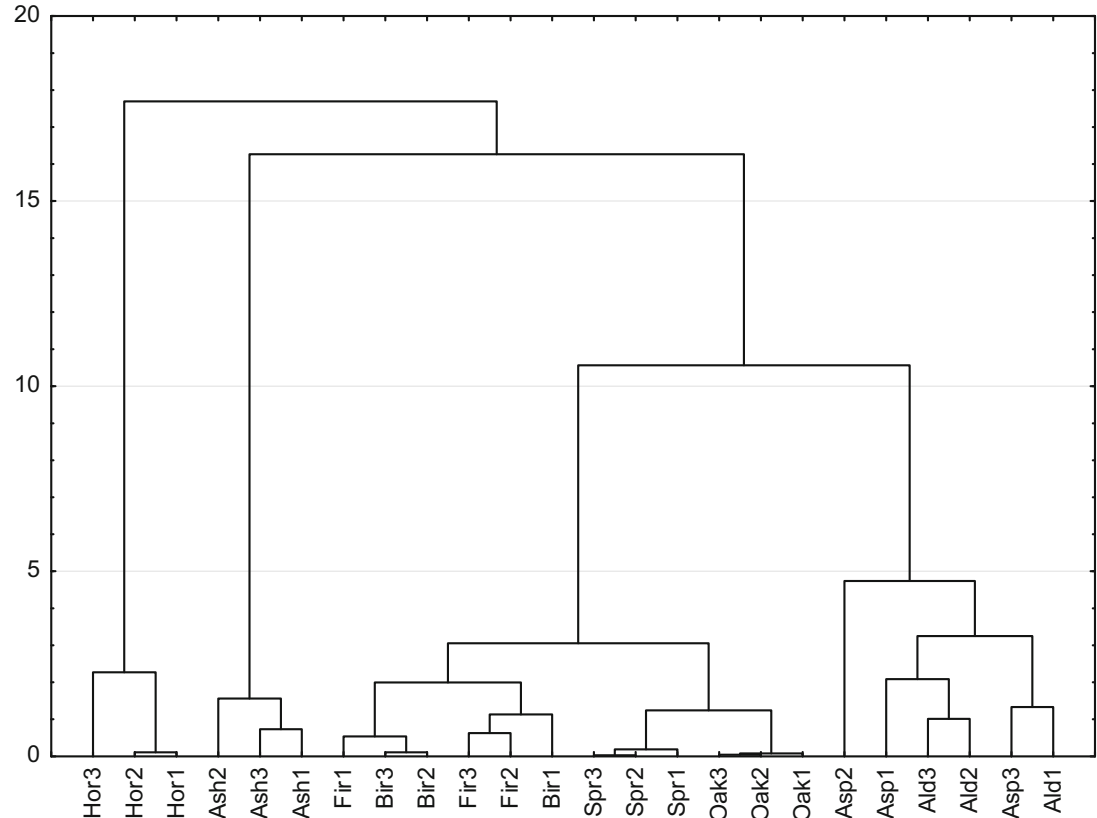

analysed the composition of leachate obtained through rinsing beech logs and determined a decrease of potassium concentration in the leachate originating from wood in the IV DC in relation to I, II and III DCs. In the study conducted by the above authors, the concentration of nitrate, ammonium, $\mathrm{Ca}$ and $\mathrm{Mg}$ ions was at its highest in the wood in the highest decay class and the obtained ion contents in the leachate from beech wood were similar to the contents observed in the present study for oak wood. In the present study, the release of potassium with the advancement of wood decomposition remained at a similar level or was slightly decreased. The wood of oak and spruce were exceptions, as slightly higher levels of potassium were found to be released at the higher decay levels.

Another cause of higher levels of ions leached from wood in the higher decay class is the change of physical properties of decomposing wood. The study of, among others, Christensen and Vesterdal (2003), Laiho and Prescott (2004) and Yang et al. (2010) illustrated how the wood thickness is greatly decreased with the progress of decomposition level. This reduction results in increased porosity and water capacity of the wood, facilitating water penetration to wood and leaching of ions released during decomposition. Another cause determining the probability of water to penetrate wood,
Fig. 8 The result of agglomeration with Ward's method of filtrates from deadwood in $\mathrm{V}$ decay classes (variables used in the analysis, anion content); Ald common alder, Asp common aspen, Ash common ash, Oak pedunculate oak, Hor hornbeam, Bir silver birch, Fir silver fir, Spr Norway spruce; 1, 2 and 3-repetitions of logs in each species

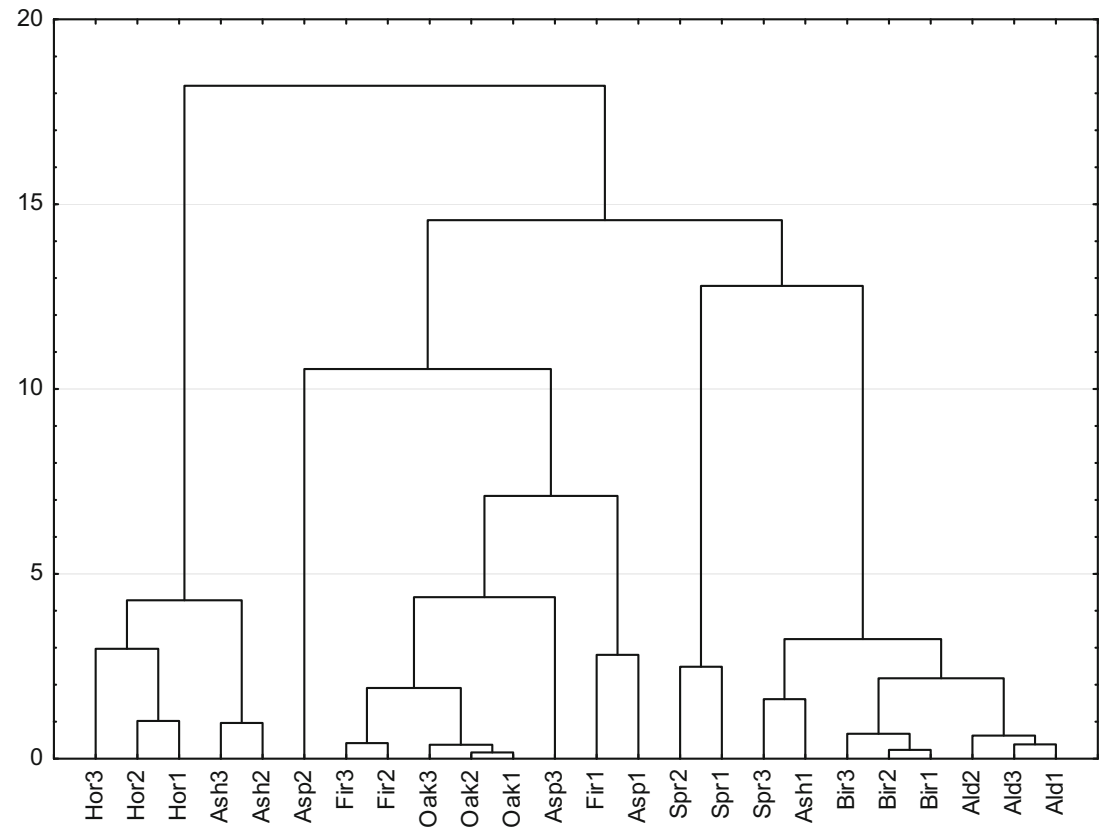


while simultaneously determining the composition of ions leached from wood, is the structure of deadwood surface and the presence of bark and other "coats", potentially reducing the possibility of water penetrating deadwood. The surface of the studied wood of different species in decay class III is mostly covered with bark, which may be partially cracked or chipped, yet it remains as a perfect layer preventing water penetration inside the log. Water flowing on the surface of logs covered with outer bark leaches different substances from it, and the concentration of these substances may reach 50 $75 \%$ of the concentration of these substances released from wood at higher decomposition stages (Bade et al. 2015). In general, logs in the higher decay class (IV) are deprived of bark, yet the surface of the log may be covered by scattered patches of mosses or lichens, creating an additional cover. The form of logs is oval, producing partial flow of water on the surface and a lower rate of water penetration in the wood. Highly decomposed wood (in the highest decay classes) loses content, and its oval shape can be entirely overgrown with mosses, yet the irregular outer surface, with numerous pits and fissures, facilitates water penetration inside the structure of highly decomposed logs (Harmon et al. 1986). Fukasawa et al. (2014) proved that wood at the advanced decomposition stage may retain tenfold more water compared to wood at the initial decay stage.

In this study, the characteristics of ions released from birch wood with the progress of decomposition exhibited different patterns from those obtained from other species. At the III decomposition stage, birch wood had already released large amounts of ions (particularly of calcium, magnesium, potassium, ammonium and nitrate anion), and with the intensification of birch wood decomposition, the amount of these ions flowing to the filtrate was vastly reduced. This phenomenon may be caused by relatively rapid decomposition of birch wood. During the field study, a strong "humification" of birch logs was observed, which, even in the DC V retained whole fragments of compact bark, under which aggregations of mycelium cords were observed, capable of full decomposition of log internal portions. It is possible that the relatively high durability of the birch bark, resulting from high content of suberin (Kociołek-Balawejder and Żebrowska 2009), has a stimulating effect on the log decomposition by means of maintaining high wood humidity inside the log.

In the conducted study, a strong variation of the ion composition of filtrate from different wood species was determined in comparable decay classes (DCs). This state stems from the considerable differences of the chemical composition of wood from different species, which has previously been demonstrated in numerous studies (Prescott and Laiho 2002; Laiho and Prescott 2004). Wood of coniferous species is less abundant with such macro nutrients as $\mathrm{N}, \mathrm{P}, \mathrm{K}, \mathrm{Ca}$ and $\mathrm{Mg}$ than deciduous wood, and the higher concentration of resinous substances and different chemical composition of the lignins may vastly hinder the microbial processes of wood decomposition in coniferous species (Kögel-Knabner 2002). Within these groups, notable differences were also observed (Holub et al. 2001; Prescott and Laiho 2002). It was demonstrated that changes in the content of certain macro nutrients depend on their initial content, which refers particularly to magnesium and potassium. Changes of nitrogen content are strongly linked to the ratio of this macronutrient to the phosphorus content in decomposing wood (Laiho and Prescott 2004). In the conducted study, birch, aspen and hornbeam (at earlier decomposition stages) were the tree species to release higher amounts of cations to the filtrate and eventually to soil, whereas in V DC, the highest amounts of cations were released by ash, aspen, hornbeam and alder wood. In terms of anion release, these species were aspen and hornbeam.

\section{Conclusions}

In our study, we established the degree of significance of the species and decomposition stage for the levels of ions released from deadwood. At the highest decomposition stage (V DC), wood tends to release more ions to the topsoil than wood characterised by a lower decay class. The mean differences are $30-50 \%$ in the case of cations and $50-100 \%$ in the case of anions. An exception from the rule is the wood of birch, which in the III decay class releases more ions than in its higher decay classes. This mainly concerns calcium, magnesium, potassium and ammonium cations, which are released at high levels from birch wood in the III decay classes. When comparing the ionic composition of leachate released from wood of coniferous and deciduous tree species, the latter are characterised by higher cation concentrations in comparison to coniferous species. Among the deciduous species, the wood of such species as ash, hornbeam, aspen, birch and alder has the most favourable effect on soil through supply with ionic substances. Ash wood releases high amounts of calcium; hornbeam wood releases magnesium and sodium; and aspen releases calcium, potassium and nitrate anions. The leachate from alder wood is rich in ammonium, whereas decomposing birch wood supplies soil with large amounts of magnesium, potassium and ammonium. From the analysed coniferous species, fir wood has a more favourable effect in terms of ion release to soil than spruce wood. Fir wood, especially at advanced decomposition stage, releases large levels of calcium and nitrate anions, whereas spruce wood provides relatively high levels of phosphate and sulfate anions to the soil solution. 
Funding information The project was financed by the National Science Centre, Poland: decision no. DEC-2016/21/D/NZ9/01333.

Open Access This article is distributed under the terms of the Creative Commons Attribution 4.0 International License (http:// creativecommons.org/licenses/by/4.0/), which permits unrestricted use, distribution, and reproduction in any medium, provided you give appropriate credit to the original author(s) and the source, provide a link to the Creative Commons license, and indicate if changes were made.

\section{References}

Bade C, Jacob M, Leuschner C, Hauck M (2015) Chemical properties of decaying wood in an old-growth spruce forest and effects on soil chemistry. Biogeochemistry 122:1-13

Christensen M, Vesterdal L (2003) Physical and chemical properties of decaying beech wood in two Danish forest reserves. Nat-Man Working Report 25. www.flec.kvl.dk/natman

Ciach M (2011) Dead and dying trees in forest ecosystem - quantity, quality, and diversity. Studia i Materiały CEPL w Rogowie 2:186199

Cotrufo MF, Wallenstein MD, Boot CM, Denef K, Paul E (2013) The Microbial Efficiency-Matrix Stabilization (MEMS) framework integrates plant litter decomposition with soil organic matter stabilization: do labile plant inputs form stable soil organic matter? Glob Chang Biol 19:988-995

Fukasawa Y, Katsumata S, Mori AS, Osono T, Takeda H (2014) Accumulation and decay dynamics of coarse woody debris in a Japanese old-growth subalpine coniferous forest. Ecol Res 29: 257-269

Harmon ME, Franklin JF, Swanson FJ, Sollins P, Gregory SV, Lattin JD, Anderson NH, Cline SP, Aumen NG, Sedell JR, Lienkaemper GW, Cromack K, Cummins KW (1986) Ecology of coarse woody debris in temperate ecosystems. Adv Ecol Res 15:133-302

Holub SM, Spears JDH, Lajtha K (2001) A reanalysis of nutrient dynamics in coniferous coarse woody debris. Can J For Res 31:1894-1902

Kociołek-Balawejder E, Żebrowska MK (2009) Birch tree biomass - the ways of its practical applications. Prace Naukowe Uniwersytetu Ekonomicznego we Wrocławiu 57:252-265

Kögel-Knabner I (2002) The macromolecular organic composition of plant and microbial residues as inputs to soil organic matter. Soil Biol Biochem 34:139-162

Krankina ON, Harmon ME, Griazkin AV (1999) Nutrient stores and dynamics of woody detritus in a boreal forest: modeling potential implications at the stand level. Can J For Res 29:20-32

Kuehne C, Donath C, Müller-Using SI, Bartsch N (2008) Nutrient fluxes via leaching from coarse woody debris in a Fagus sylvatica forest in the Solling Mountains, Germany. Can J For Res 38:2405-2413
Laiho R, Prescott CE (2004) Decay and nutrient dynamics of coarse woody debris in northern coniferous forests: a synthesis. Can J For Res 34:763-777

Lassauce A, Paillet Y, Jactel H, Bouget C (2011) Deadwood as a surrogate for forest biodiversity: meta-analysis of correlations between deadwood volume and species richness of sproxylic organisms. Ecol Indic 11:1027-1039

Lombardi F, Cherubini P, Tognetti R, Cocozza C, Lasserre B, Marchetti M (2013) Investigating biochemical processes to assess deadwood decay of beech and silver fir in Mediterranean mountain forests. Ann For Sci 70:101-111

Magnússon RJ, Tietema A, Cornalissen JHC, Hefting MM, Kalbitz K (2016) Tamm Review: Sequestration of carbon from coarse woody debris in forest soils. For Ecol Manag 377:1-15

Maser C, Anderson RG, Cromak K, Williams JT, Martin RE (1979) Dead and down woody material. In: Thomas JW (ed) Wildlife habitats in managed forests: the blue mountains of Oregon and Washington. USDA Forest Service Agricultural Handbook, vol 553. pp 78-95

Pichler V, Homolák M, Skierucha W, Pichlerová M, Ramírez D, Gregor J, Jaloviar P (2011) Variability of moisture in coarse woody debris from several ecologically important tree species of the Temperate Zone of Europe. Ecohydrology 5:424-434

Prescott CE, Laiho R (2002) The nutritional significance of coarse woody debris in three Rocky Mountain coniferous forests. USDA Forest Service Gen. Tech. Rep. PSW-GTR-181

Rock J, Badeck F-W, Harmon ME (2008) Estimating decomposition rate constants for European tree species from literature sources. Eur J For Res 127:301-313

Russell MB, Fraver S, Aakala T, Gove JH, Woodall CW, D'Amato AW, Ducey MJ (2015) Quantifying carbon stores and decomposition in dead wood: a review. For Ecol Manag 350:107-128

Shorohova E, Kapitsa E (2014) Influence of the substrate and ecosystem attributes on the decomposition rates of coarse woody debris in European boreal forests. For Ecol Manag 315:173-184

Van-Camp L, Bujarrabal B, Gentile AR, Jones RJA, Montanarella L, Olazabal C, Selvaradjou SK (2004) Reports of the Technical Working Groups established under the Thematic Strategy for Soil Protection. EUR 21319EN/3. Office for official Publications of the European Communities, Luxembourg, p 872

WRB (World Reference Base For Soil Resource) (2014) FAO, ISRIC and ISSS

Yang F, Li Y, Zhou Y, Wenigmann KO, Zhang D, Wenigmann M, Liu S, Zhang Q (2010) Dynamics of coarse woody debris and decomposition rates in an old-growth forest in lower tropical China. For Ecol Manag 259:1666-1672

Zell J, Gerald K, Marc H (2009) Predicting constant decay rates of coarse woody debris - a meta-analysis approach with a mixed model. Ecol Model 220:904-912

Zhou L, Dai L, Gu H, Zhong L (2007) Review on the decomposition and influence of coarse woody debris in forest ecosystem. J For Res 18:48-54 